\title{
Cultural spaces inside and outside caves: a study in Guam, western Micronesia
}

Mike T. Carson*

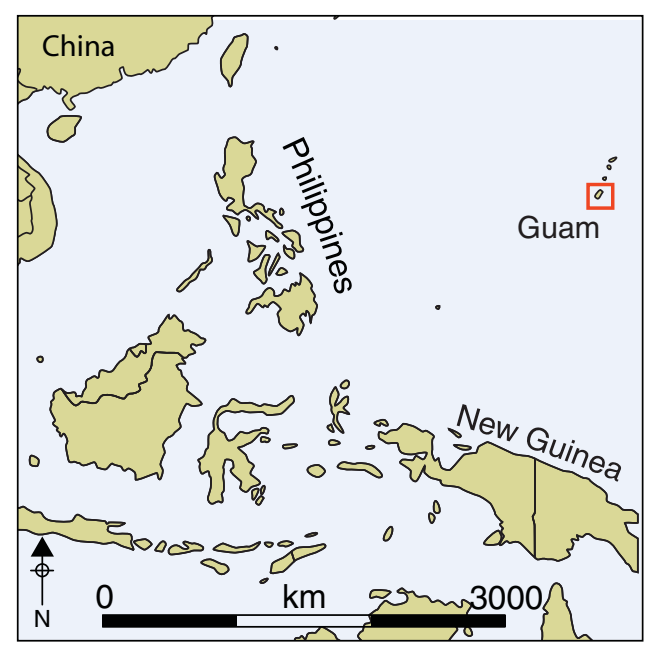

The limestone cliff face overlooking the coastline of Ritidian, on Guam, has revealed several caves with evidence of human activities. Since 2011, archaeological survey and excavation have exposed how use of the caves had changed over time, and that they were the focus of special behaviours, with quite distinct archaeology to that of nearby residential sites. To understand the significance of these caves fully, they must be contextualised within the broader framework of contemporary open-air sites. The result highlights the use of the caves for unique purposes at different times, including as water sources, venues for various art traditions and particular burial customs.

Keywords: Guam, Micronesia, cave archaeology, cultural space

\section{Introduction}

In many cultures, caves serve as places of specialised activities that are differentiated from open sites associated with more mundane aspects of human life. They are essential for allowing societies to operate within designated ritual spaces (cf. Clottes 2003; Brady \& Prufer 2005; Taçon 2005; Bergsvik \& Skeates 2012; Moyes 2012). To interpret these contexts, archaeological records within caves need to be related to contemporaneous, daily residential activities in other locales, expanding on Dixon and Schaefer's (2014) proposal that we should view caves as elements of holistic settlement patterns. A new study on Guam examines what makes caves unique through time, with reference to enigmatic rock art, burials of individuals outside conventional grave arrangements, rare artefacts and food remains, and religious rites specific to these sites. While the outside world changed in its physical composition and cultural context, caves persisted as fixed places reserved for rituals or ceremonies, even if the activities themselves changed over time.

* Micronesian Area Research Center, University of Guam, 303 University Drive, UOG Station, Mangilao, GU 96913, Guam (Email: mtcarson@uguam.uog.edu) 
Caves are found in various geologies around the world and are used by many different cultures, but some of their attributes transcend geographic boundaries. These include their location within the earth, limited natural light penetration, restricted airflow, unusual acoustics, disorientating interior surface curvatures, and other characteristics capable of significant effects upon the human senses (Montello \& Moyes 2012). Human groups never resided permanently in the dark zones of caves, but rather used them for a narrow range of activities distinct from daily life outside. Areas of caves exposed to varying degrees of natural light did, however, accommodate more frequent use, in some cases transitioning between ritual and non-ritual spaces.

The Ritidian area of northern Guam consists of limestone terrain with innumerable caves and cavities adjoining a sandy coastal plain with a series of archaeological layers spanning human presence in the region since $1500 \mathrm{BC}$. The social context of the landscape changed concurrently with the physical features, such as coastal morphology, ecology and forest composition. The cave formations, however, remained constant as special places (Figure 1). The precise nature of activities in the caves changed along with the cultural sequences observed in the site records outside, providing a basis to learn about the long-term evolution of the relationships between these distinct but connected venues.

\section{Ritidian Caves}

Ritidian is part of the limestone plateau of northern Guam, originally formed by corals during the Pliocene Epoch. The cliff face at Ritidian is riddled with caves, making a distinctive landscape (Figure 2). The individual caves are classified as solution cavities (where the limestone was dissolved by slightly acidic rainwater filtration) or flank margin caves (dissolved by brackish water at the interface of fresh and marine water layers) (Tabarosi 2006).

The magnitude of tectonic uplift and tilting was negligible during the time of human presence, and it did not affect the ability of people to access these particular caves. The rate of uplift has not been measured precisely, but the uppermost terrace at $200 \mathrm{~m}$ asl is estimated to be five million years old (Tabarosi 2006). Change in sea level was more substantial during this period. It was, on average, $1.8 \mathrm{~m}$ higher between 3000 and $1100 \mathrm{BC}$ than today's level (Dickinson 2000), confirmed by elevations and direct radiocarbon-dating of fossil reefs specifically at Ritidian (Carson 2011, 2012a, 2014a \& b). Slight horizontal tilting is evident from the displacement of stalagmites, stalactites and conjoined pillars by up to $0.5 \mathrm{~m}$ from their original vertical formations.

The caves bearing archaeological evidence at Ritidian may be categorised into those open at ground level and those that can be reached only by climbing the cliff face. Further distinctions include the distributions of midden deposits, burial features, pictographs on the cave walls and grinding basins in the limestone shelves outside the cave mouths. Additional clues to cultural use are offered by the water pools, areas of active stalactite and stalagmite growth, areas for standing or crawling, zones with and without natural lighting, exposed rock floors $v$ s loose sediment, and other variables (Pastoors \& Weniger 2011).

(C) Antiquity Publications Ltd, 2017 

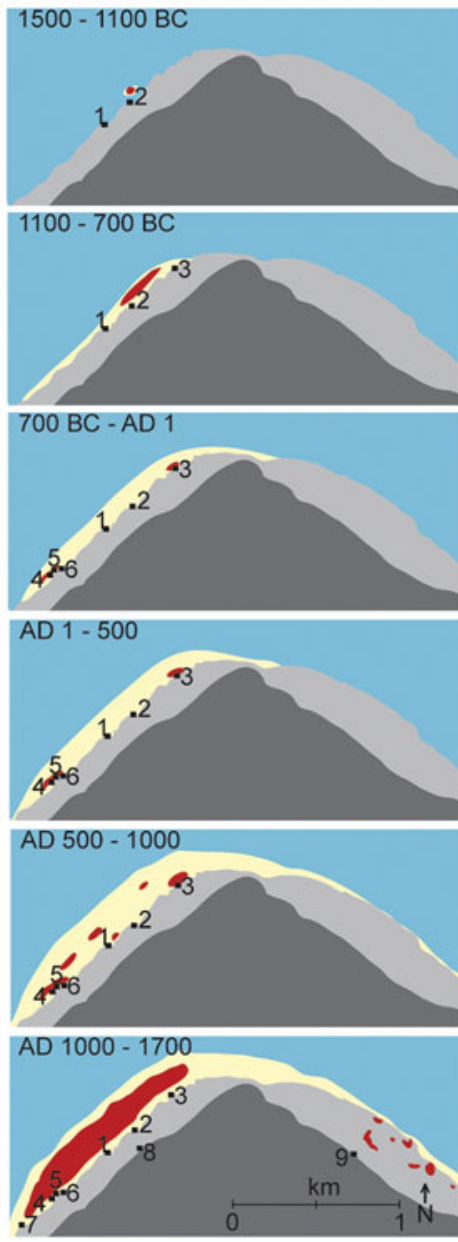

Residential site area

Ocean

Beach sand

Lower limestone terrace

Upper limestone terrace
1, 2 = use of light-zone overhang, possible pictographs

1, 2 = use of light-zone overhang, possible pictographs $3=$ use of exterior, possible pictographs

1,2 = use of light-zone overhang, possible pictographs 3 = use of exterior, possible pictographs, external cliff-base habitation

4, 5, 6 = external cliff-base habitation

1, 2 = use of light-zone overhang, possible pictographs

$3=$ use of exterior, possible pictographs, external cliff-base habitation

4 = internal cultural deposit, possible pictographs

$5,6=$ external cliff-base habitation

1, 2 = use of light-zone overhang, possible pictographs

$3=$ use of exterior, possible pictographs, external cliff-base habitation

4 = internal cultural deposit, possible pictographs

$5,6=$ external cliff-base habitation

1, 2 = use of light-zone overhang, pictographs, interior burial bedrock mortar

$3=$ use of exterior, pictographs, bedrock mortar, exterior cliff-base burial

$4,5=$ interior cultural deposit, pictographs, interior burial

$6=$ interior burial

7 = bedrock mortar

$8=$ interior cultural deposit, pictographs, interior burial

$9=$ interior cultural deposit, bedrock mortar

$1=$ Ritidian Pictograph Cave, lower terrace, ground level

2 = Ritidian Beach Cave, lower terrace, ground level

$3=$ Ritidian Gate Cave, lower terrace, ground level

4 = Upper Cave, lower terrace, climb to enter

$5=$ Unnamed Cave, lower terrace, climb to enter

$6=$ Lower Cave, lower terrace, ground level

$7=$ West End Cave, lower terrace, ground level

$8=$ Ritidian View Cave, upper terrace, climb to enter

$9=$ Hilitai Cave, upper terrace, climb to enter

Figure 1. Map showing Ritidian landscape chronology, noting the relationship of the caves to open habitation sites over time.

These caves were used in greater numbers and increasing intensity over time, while the kinds of activities changed at each cave and, more generally, within the local resident communities (see Figure 1). New survey and excavation results build on a previously reported landscape chronology (Carson 2012a, 2014b), expanding the geographic coverage, refining the overall sequence and situating the caves within larger contexts. 

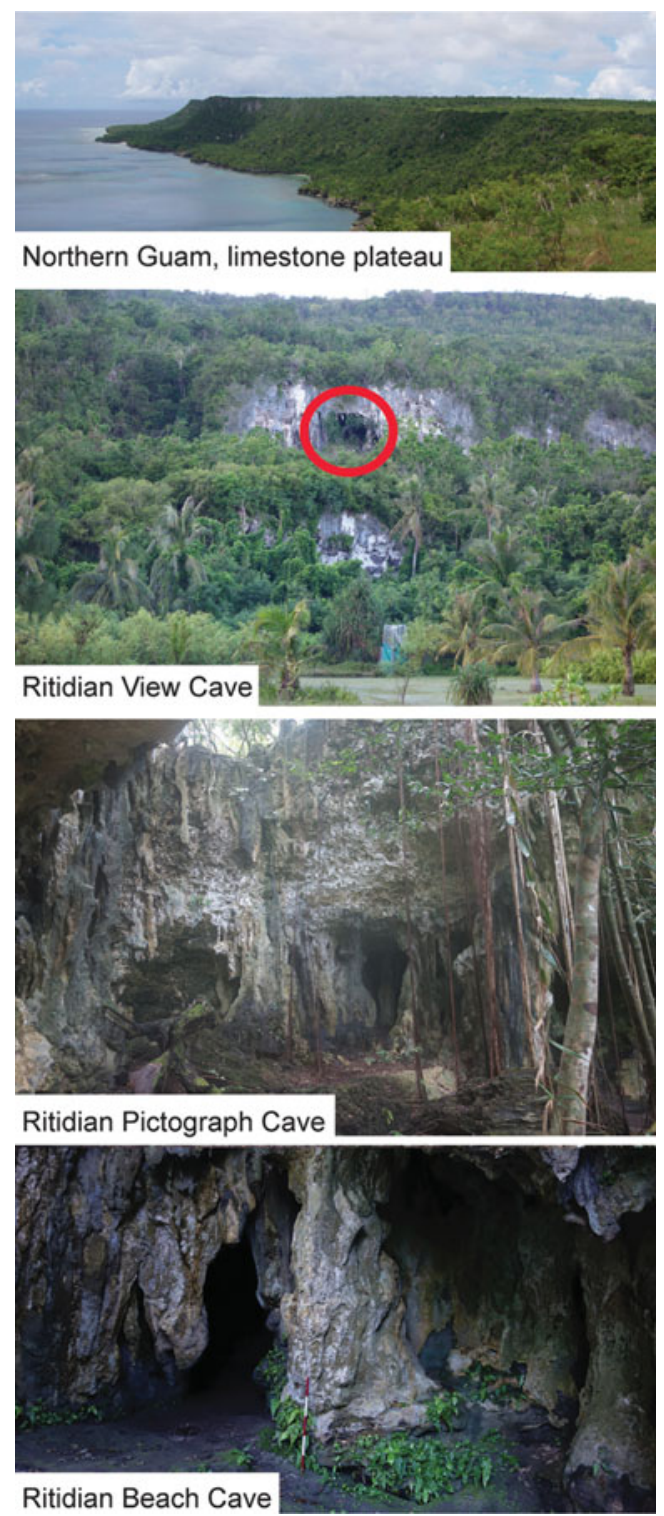

Figure 2. Photographs showing the limestone landscape at Ritidian and entrances to View, Pictograph and Beach Caves (photographs by the author).

\section{Ritidian between 1500 and 1100 BC}

The coastal zone at Ritidian has transformed substantially since the first human settlement at $1500 \mathrm{BC}$, and a growing population continually adapted to the changing landform and ecology. Around 1500 BC, people lived in one small area outside of Ritidian Beach Cave (shown in Figure 1) of a larger inter-tidal or shallow sub-tidal zone, where they generated a layer of broken pottery, stone tools, shell beads and food refuse within a lagoon-bed of (C) Antiquity Publications Ltd, 2017 


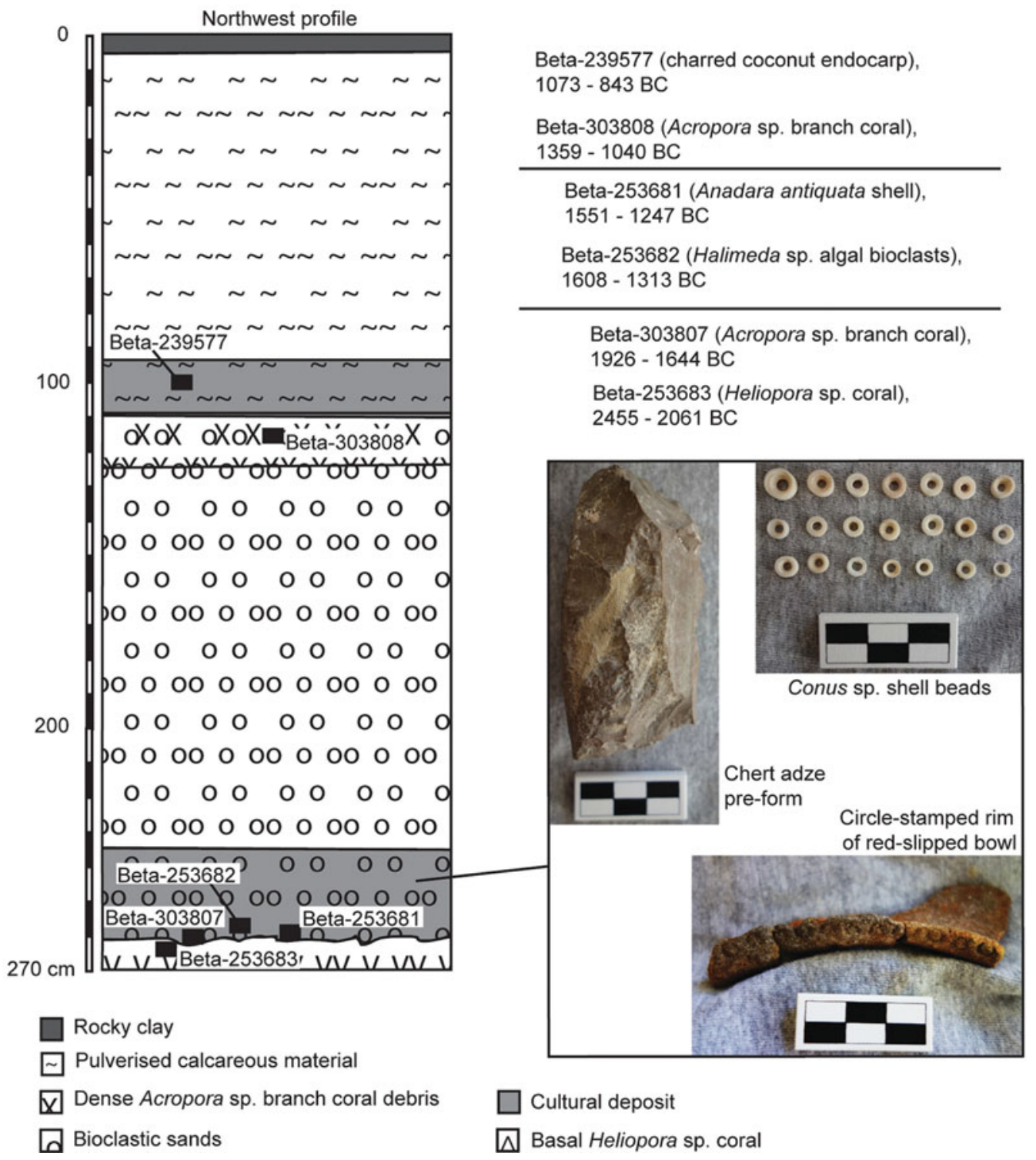

Figure 3. The earliest evidence of habitation at Ritidian; excavation (fenceline pit 35) at an open habitation site about $50 \mathrm{~m}$ north of Ritidian Beach Cave. Artefact pictures show scale bars in $10 \mathrm{~mm}$ increments.

algal bioclasts (Figure 3; Table 1). The shallow-water palaeo-lagoon supported meadows of Halimeda sp. algae over a broad area, meeting the base of the limestone cliff (now about $200 \mathrm{~m}$ inland), with a few scattered patches of unstable beach sands. This early settlement at Ritidian was among the first in the Mariana Islands and indeed Remote Oceania more generally (Carson \& Kurashina 2012; Carson 2014c). The habitation layer contains broken red-slipped pottery, mostly undecorated but with one instance of a circle-stamped rim, a 
Table 1. Radiocarbon details of samples relevant to the text.

\begin{tabular}{|c|c|c|c|c|c|}
\hline Beta-\# & Material & $\begin{array}{c}{ }^{13} \mathrm{C} /{ }^{12} \mathrm{C} \\
\text { ratio }(\% 0)\end{array}$ & $\begin{array}{l}\text { Conventional } \\
\text { age (years BP) }\end{array}$ & $\begin{array}{l}\text { Marine reservoir } \\
\text { correction }(\Delta \mathrm{R})^{*}\end{array}$ & $\begin{array}{l}\text { 2-sigma calibration } \\
\text { (calendar years) }\end{array}$ \\
\hline \multicolumn{6}{|c|}{ Fenceline pit 35} \\
\hline 239577 & carbonised coconut endocarp & -25.4 & $2810 \pm 40$ & not applicable & $\begin{array}{c}1073-1066 \text { BC }(0.77 \% \\
1057-843 \text { BC }(94.7 \%)\end{array}$ \\
\hline 303808 & Acropora sp. branch coral & -1.1 & $3260 \pm 30$ & $-44 \pm 41$ & 1359-1040 BC (95.4\% \\
\hline 253681 & Anadara sp. shell & -0.7 & $3420 \pm 40$ & $-44 \pm 41$ & 1551-1247 BC (95.4\% \\
\hline 253682 & Halimeda sp. algal bioclast & +5.3 & $3480 \pm 40$ & $-44 \pm 41$ & $1608-1313$ BC (95.4\% \\
\hline 303807 & Acropora sp. branch coral & -3.0 & $3750 \pm 30$ & $-44 \pm 41$ & 1926-1644 BC (95.4\% \\
\hline 253683 & Heliopora sp. coral & +4.2 & $3860 \pm 30$ & $-44 \pm 41$ & 2455-2061 BC (95.4\% \\
\hline
\end{tabular}

\section{Ritidian Beach Cave}

\begin{tabular}{|c|c|c|c|c|c|}
\hline 444229 & human bone & -17.5 & $2180 \pm 30$ & not applicable & $361-168$ BC (95.4\%) \\
\hline 433372 & charcoal & -26.3 & $2470 \pm 30$ & not applicable & $\begin{array}{c}768-476 \text { BC }(92.4 \%) \\
464-453 \text { BC }(1.2 \%) \\
445-431 \text { BC }(1.8 \%)\end{array}$ \\
\hline 424685 & Anadara sp. shell & -1.2 & $2780 \pm 30$ & $-44 \pm 41$ & 768-457 BC (95.4\%) \\
\hline 424686 & Anadara sp. shell & -0.7 & $3400 \pm 30$ & $-44 \pm 41$ & $1491-1231 \mathrm{BC}(95.4 \%)$ \\
\hline 433371 & Anadara sp. shell & -1.9 & $3480 \pm 30$ & $-44 \pm 41$ & $\begin{array}{c}1604-1344 \text { BC }(95.1 \%) \\
1331-1320 \text { BC }(0.3 \%)\end{array}$ \\
\hline
\end{tabular}


Table 1. Continued.

\begin{tabular}{|c|c|c|c|c|c|}
\hline Beta-\# & Material & $\begin{array}{l}{ }^{13} \mathrm{C} /{ }^{12} \mathrm{C} \\
\text { ratio }(\% 0)\end{array}$ & $\begin{array}{l}\text { Conventional } \\
\text { age (years BP) }\end{array}$ & $\begin{array}{l}\text { Marine reservoir } \\
\text { correction }(\Delta \mathrm{R})^{*}\end{array}$ & $\begin{array}{l}\text { 2-sigma calibration } \\
\text { (calendar years) }\end{array}$ \\
\hline \multicolumn{6}{|c|}{ Ritidian Pictograph Cave } \\
\hline \multirow[t]{3}{*}{418951} & charcoal & -24.0 & $1670 \pm 30$ & not applicable & AD $258-285(6.0 \%)$ \\
\hline & & & & & AD $290-295(0.4 \%)$ \\
\hline & & & & & $\mathrm{AD} 321-428(89.0 \%)$ \\
\hline 418952 & charcoal & -25.0 & $1870 \pm 30$ & not applicable & $\mathrm{AD} 73-226(95.4 \%)$ \\
\hline 418950 & Anadara sp. shell & -1.9 & $2570 \pm 30$ & $-44 \pm 41$ & $483-191$ BC $(95.4 \%)$ \\
\hline 355871 & Anadara sp. shell & -1.8 & $3330 \pm 30$ & $-44 \pm 41$ & $1418-1144$ BC (95.4\%) \\
\hline 424684 & Halimeda sp. algal bioclast & +4.2 & $3850 \pm 30$ & $-44 \pm 41$ & $2071-1752$ BC (95.4\%) \\
\hline 355872 & Halimeda sp. algal bioclast & +4.2 & $3860 \pm 30$ & $-44 \pm 41$ & $2097-1772$ BC (95.4\%) \\
\hline 414213 & Halimeda sp. algal bioclast & +4.0 & $3900 \pm 30$ & $-44 \pm 41$ & $2143-1842$ BC (95.4\%) \\
\hline 383491 & Barbatia sp. shell & +1.3 & $4300 \pm 30$ & $-44 \pm 41$ & $2701-2377$ BC (95.4\%) \\
\hline \multicolumn{6}{|c|}{ Ritidian Gate Cave } \\
\hline 263447 & carbonised coconut endocarp & -24.5 & $790 \pm 40$ & not applicable & AD $1169-1280(95.4 \%)$ \\
\hline 263448 & carbonised coconut endocarp & -24.5 & $2510 \pm 40$ & not applicable & 796-509 BC (95.4\%) \\
\hline 263450 & carbonised coconut endocarp & -24.0 & $2510 \pm 40$ & not applicable & 796-509 BC (95.4\%) \\
\hline \multirow[t]{2}{*}{414211} & charcoal & -24.6 & $2460 \pm 30$ & not applicable & $758-678$ BC (29.5\%) \\
\hline & & & & & $672-429$ BC (65/9\%) \\
\hline 414212 & Acropora sp. branch coral & -2.5 & $3140 \pm 30$ & $-44 \pm 41$ & $1191-889$ BC (95.4\%) \\
\hline
\end{tabular}

* = Marine reservoir corrections follow the calculations specifically for the Ritidian site (Carson 2010).

\section{Research}




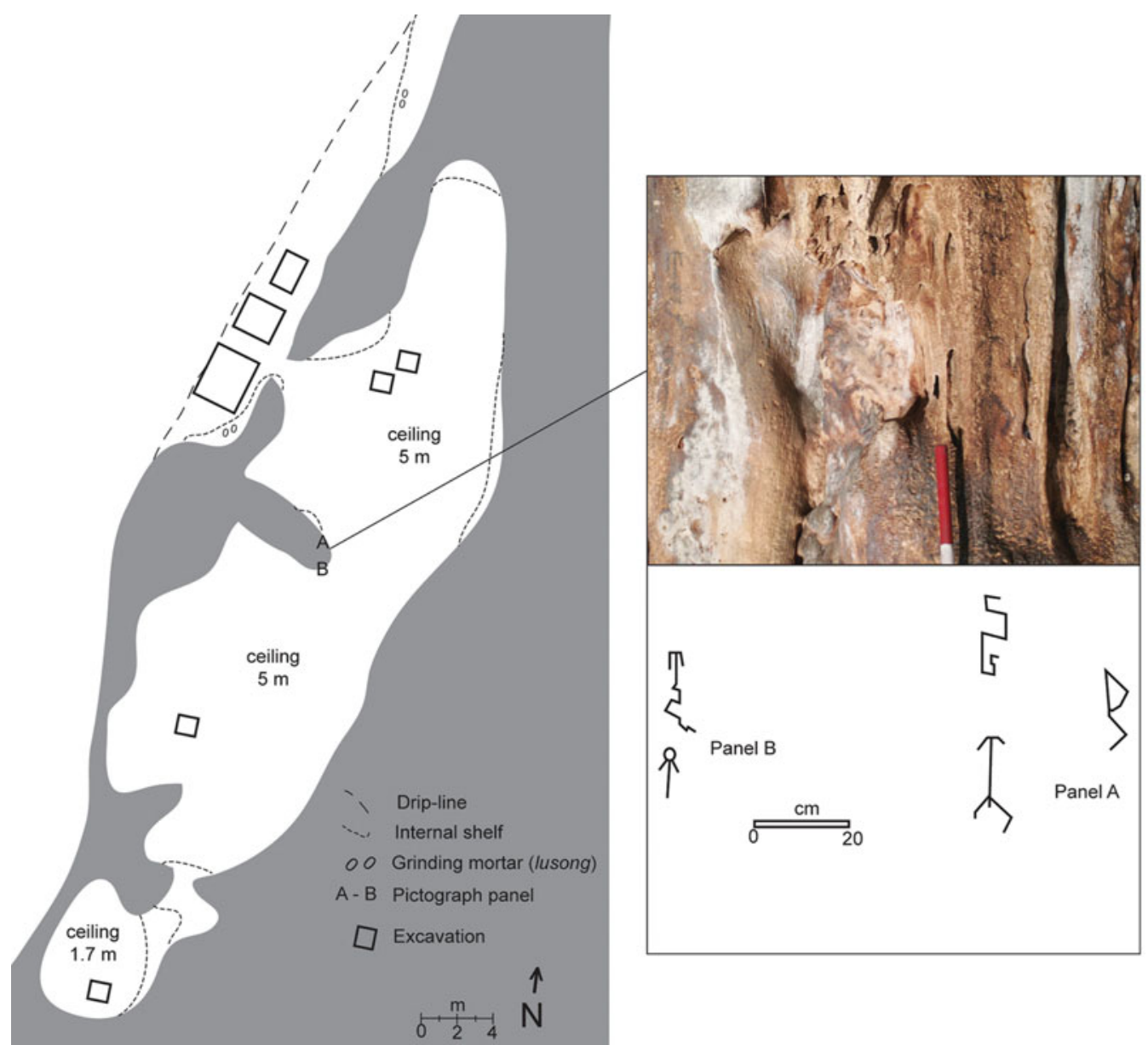

Figure 4. Map of Ritidian Beach Cave showing excavation trenches and pictograph panels ( $A$ \& B). Rock art depicting black figurines is shown with scale bars in $200 \mathrm{~mm}$ increments (photograph by the author).

chert adze blank or preform, Conus sp. shell beads, shellfish remains primarily of Anadara sp., and a few fish bones.

While people were learning how to live on the isolated shores of the Pacific for the first time in human history, they must have observed the cave openings along the base of the cliff near the initial settlement. Several caves were accessible, for instance at the two overhangs at the ground-level entrances to Ritidian Beach Cave (also known as 'First Cave') and Ritidian Pictograph Cave (also known as 'Star Cave') (Figures 4-7). Dated layers of lagoon sands show that the tide entered the mouths of the caves. Some of the low spots in the caves' floors must once have contained freshwater pools, as they were level with or below the island's aquifer, and above the sea level of the time. Even without standing pools in the cave floors, the stalactites constantly drip with water. The oldest cultural deposits were constrained to the exterior overhang areas, while the deeper cave interiors showed no cultural deposits until later periods.

(C) Antiquity Publications Ltd, 2017 

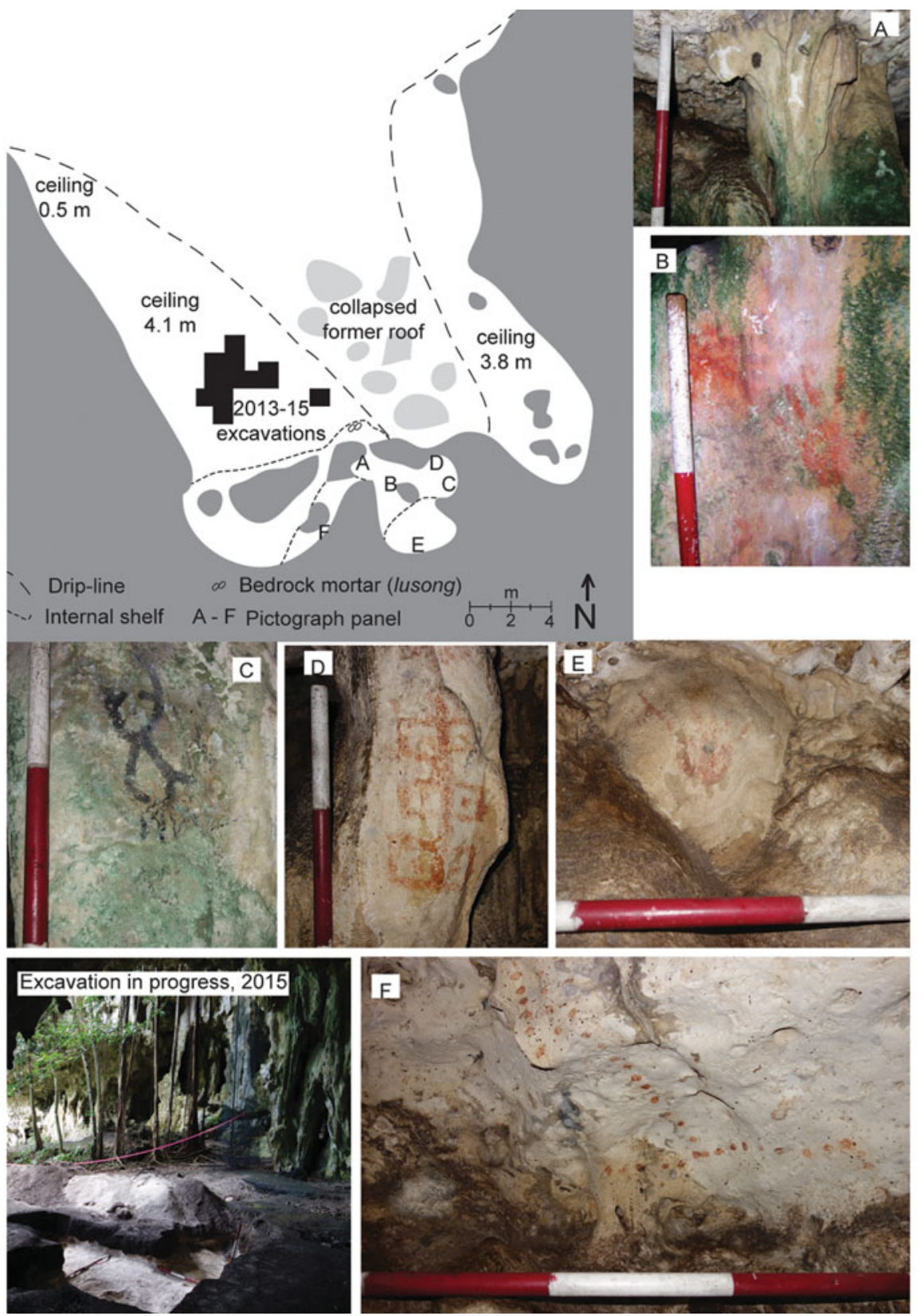

Figure 5. Map of Ritidian Pictograph Cave. Rock art pictures show scale bars in $200 \mathrm{~mm}$ increments (photographs by the author).

The earliest cultural activity at both Beach and Pictograph Caves involved a different set of artefacts and midden deposits to those from the contemporary open settlement. The Beach Cave excavation revealed the earliest cultural deposit, emplaced within the lagoon sand and yielding thin red-slipped pottery, including rare pieces of a footring (the only one 

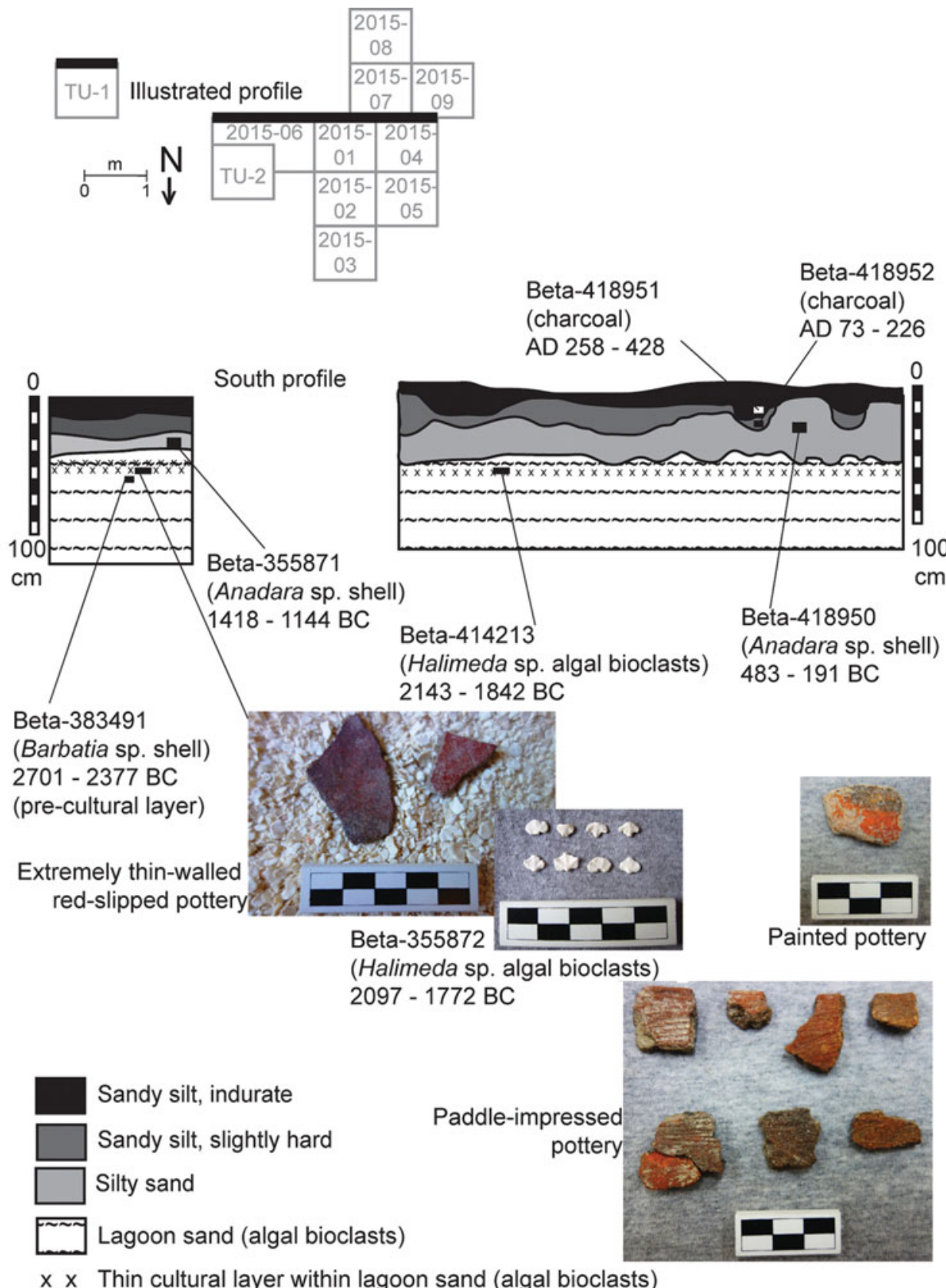

Figure 7. Plan of excavation, radiocarbon dates, stratigraphy and selected artefacts from the exterior of Ritidian Pictograph Cave. Selected artefacts are from the layer. Artefact pictures show scale bars in $10 \mathrm{~mm}$ increments (photographs by the author).

of its kind so far known in the Marianas), a handle appendage (one of only four known) and finely decorated motifs. Other unusual items included a carved harpoon or spear-point fragment of human bone, a small polished adze, an ornate shell coconut grater and several 
cut-and-polished shell beads, rings and discs of Conus sp. and Cypraea sp. Also emplaced within the ancient lagoon-sand layer, the Pictograph Cave's earliest cultural horizon was only $250-500 \mathrm{~mm}$ thick, disclosing pieces of extremely thin-walled red-slipped pottery, as well as the region's only known instances of bowl fragments impressed by paddles wrapped by vines or rattan. Shellfish remains resembled the low-density debris at Beach Cave, but the taxa at Pictograph Cave curiously did not include Anadara sp., which was the most popular shellfish food at that time at all other known sites. Instead, the shellfish remains here consisted mostly of limpets. Nodules of bright red haematite may have been used for making the red pottery slip, but could also have formed part of the recipe for rock art inside Pictograph Cave.

Black-pigment pictographs were identified in Ritidian Beach Cave, with no other colours of rock art in this cave (Table 2). Each figure was drawn in the fully dark zone of the cave, $3.5-4.5 \mathrm{~m}$ above the cave floor and visible only with artificial lighting. These images were probably drawn by climbing along a precarious foot-width ledge in the cave wall.

Pictograph Cave contains numerous examples of bright red, dull reddish-brown, black, and white rock art. Some of the elements are superimposed, indicating a relative chronology. Bright red handprints have become overlain by later white-pigment designs of human figures. Additional bright red images of an apparent X-ray hand, a full hand and forearm, and a simple round shape were produced with the same or similar pigment mixture, but a precise age cannot be assigned. A single instance of black pigment and several dull reddish-brown images occur without superimposition. All of these are enigmatic, geometric shapes that suggest a shared albeit unclarified behavioural context. The deepest chamber contains a panel of dull reddish-brown thumbprint dots, arranged over the curvature of the cave wall in one horizontal row, with vertical columns of dots towards the left-hand side, possibly representing the ascent of the sun, moon or certain stars above the horizon as acknowledged in the colloquial name of 'Star Cave'. Other dull reddish-brown drawings depict a possible crab and varied compound geometric shapes.

\section{Ritidian between 1100 and $700 \mathrm{BC}$}

At $1100 \mathrm{BC}$, lowering sea level resulted in a new stranded berm. Occupants of an elongated settlement engaged in more intensive activities, while small pockets of beach sands were stabilising at Beach and Pictograph Caves, and (for the first time) at Gate Cave. Supplies of Anadara sp. began to dwindle with the changing coastal ecology. Their shells continued to form an appreciable portion of the midden at the beach-ridge habitation, but they appeared in low frequencies at each of the caves where limpets and other shells were instead more numerous.

In front of the cave entrances, people used distinctive forms of artefacts not seen at the beach-ridge settlement. This is especially noticeable at Gate Cave (Figure 8). A rare pottery handle was recovered, along with bold-incised decorative pottery typical of this period. Additionally, cut-and-polished fragments of human long-bone at both Gate and Beach Caves may represent by-products of spear-point manufacture, as seen in the older (C) Antiquity Publications Ltd, 2017 
Table 2. Ritidian pictographs.

\begin{tabular}{|c|c|c|c|c|}
\hline Cave & $\begin{array}{l}\text { White; } \\
\text { most probably } \\
\text { post-AD } 1000\end{array}$ & $\begin{array}{l}\text { Black; } \\
\text { potentially as early } \\
\text { as } 1500-1100 \mathrm{BC}\end{array}$ & $\begin{array}{l}\text { Bright red; } \\
\text { pre-AD } 1000 \text { and probably at } \\
\text { at least as early as } 1100-700 \mathrm{BC}\end{array}$ & $\begin{array}{l}\text { Dull reddish-brown; } \\
\text { potentially as early } \\
\text { as } 1500-1100 \mathrm{BC}\end{array}$ \\
\hline $\begin{array}{l}\text { Beach Cave; earliest use at } \\
1500-100 \mathrm{BC}\end{array}$ & & $\begin{array}{l}\text { human figures; } \\
\text { contorted figures }\end{array}$ & & \\
\hline $\begin{array}{l}\text { Pictograph Cave; earliest } \\
\text { use at } 1500-1100 \mathrm{BC}\end{array}$ & human figures & unknown shape & $\begin{array}{l}\text { handprints; hand X-ray; } \\
\text { hand-and-forearm print; round shape }\end{array}$ & $\begin{array}{l}\text { aligned thumbprint dots; } \\
\text { compound geometric shapes }\end{array}$ \\
\hline $\begin{array}{l}\text { Gate Cave; earliest use at } \\
1100-700 \mathrm{BC}\end{array}$ & & & handprint; hand X-ray & \\
\hline $\begin{array}{l}\text { Lower Cave; sparse use } \\
\text { after AD } 100 \text { but } \\
\text { intensive after AD } 1000\end{array}$ & human figures & & & \\
\hline $\begin{array}{l}\text { Upper Cave; sparse use } \\
\text { after AD } 100 \text { but } \\
\text { intensive after AD } 1000\end{array}$ & human figures & & & \\
\hline $\begin{array}{l}\text { View Cave; earliest use } \\
\text { after AD } 1000\end{array}$ & human figures & & & \\
\hline
\end{tabular}




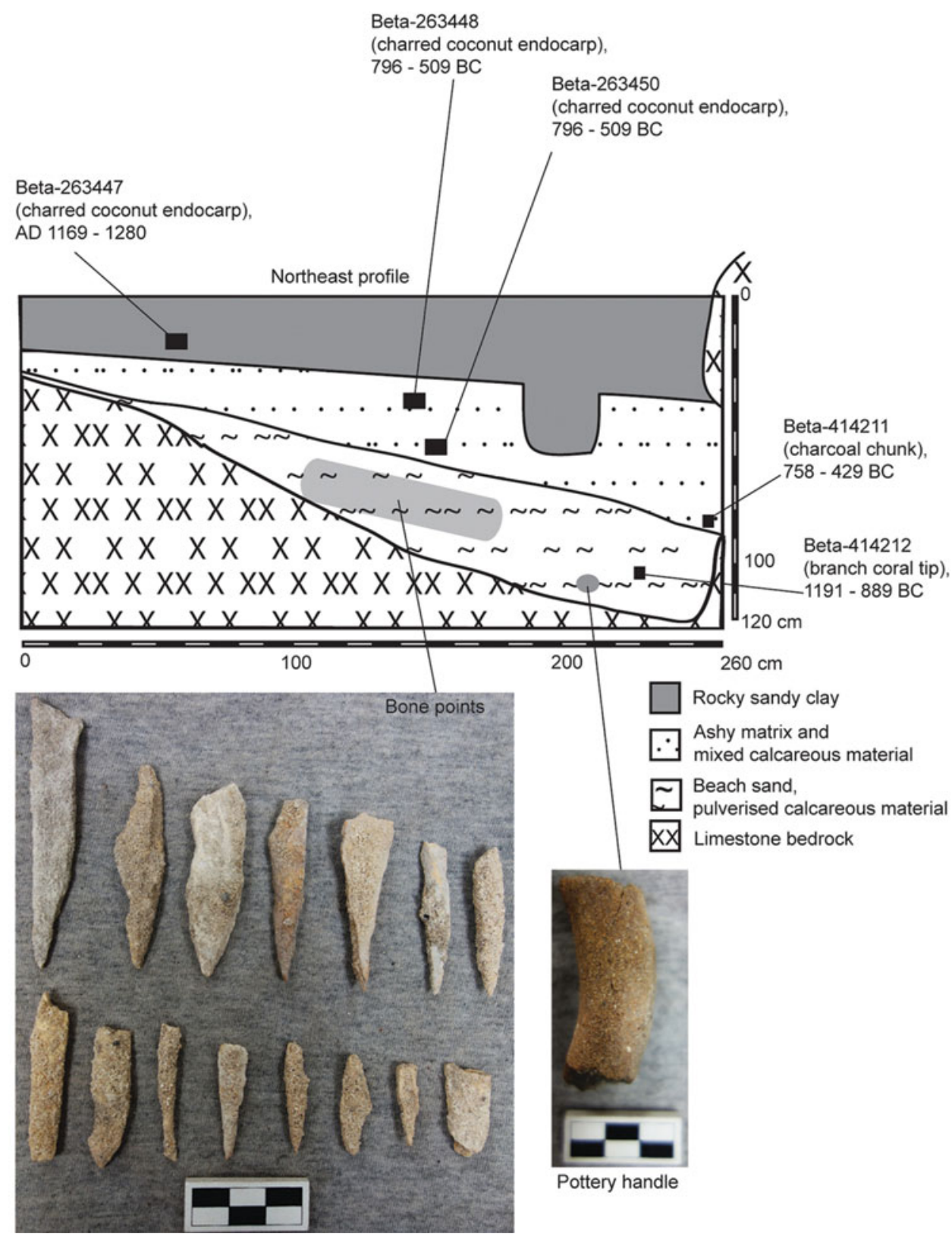

Figure 8. Stratigraphy, radiocarbon dates and selected artefacts from the excavation at the exterior of Ritidian Gate Cave. Artefact pictures show scale bars in $10 \mathrm{~mm}$ increments. Photograph by the author.

deposit at Beach Cave. The discard of human bones resembles ritual placement with a tight cluster of 25 pieces at Gate Cave, and a few pieces at the base of a narrow pit at Beach Cave bearing traces of red ochre. Ethnohistorical accounts show that bone spear tips in the Marianas were associated with both magical and technical deadliness, attributed to the power of ancestors (McNeill 2005).

(C) Antiquity Publications Ltd, 2017 
The interior of Gate Cave presents an exposed rocky floor with no sediment or cultural deposits, but a small alcove near the entrance contains a bright red handprint accompanied by an X-ray hand (Figure 9). The X-ray

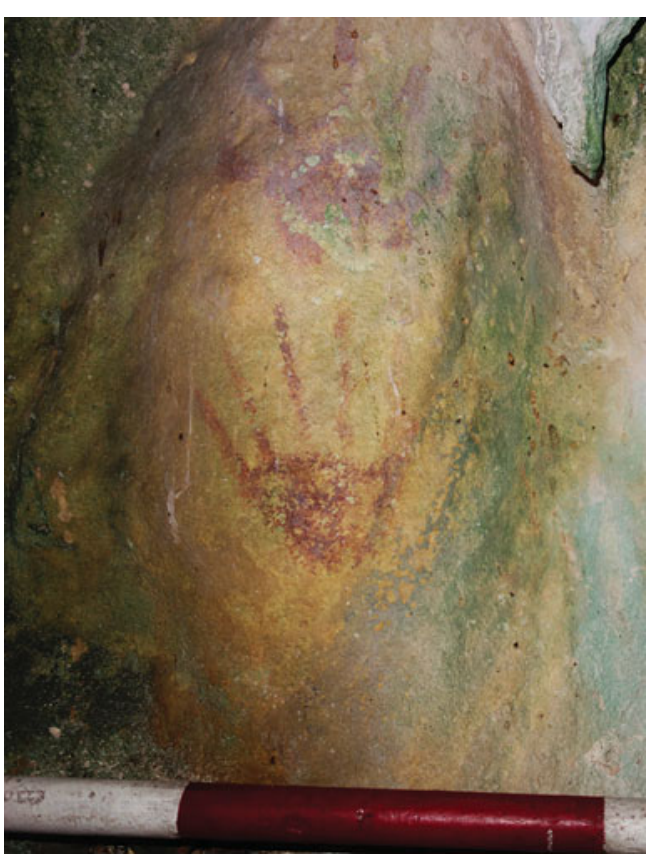

Figure 9. Rock art panel inside Ritidian Gate Cave. Scale bar is in 200mm increments (photograph by the author). motif resembles that on the back wall of Pictograph Cave, suggesting a linked context and perhaps even a similar age that probably does not pre-date $1100-700 \mathrm{BC}$ at Gate Cave. The deeper and dark zones of this cave contain further chambers but no material evidence of cultural activities.

\section{Ritidian between $700 \mathrm{BC}$ and AD 1}

Between $700 \mathrm{BC}$ and $\mathrm{AD} 1$, people began to engage more intensively with inland zones, driven by the instability of coastal ecosystems resulting from falling sea level. The same shift in resource use has been observed in islands throughout the western and central Pacific within a few centuries of the beginning of sea-level fall, becoming noticeable in the material records between 700 and 500 BC (Nunn \& Carson 2015). Specifically, at Ritidian, people began to

occupy cliff-base settlements directly outside a few of the caves, but cultural deposits did not accumulate within the caves themselves at this time.

Given the surge in the cliff-base cultural deposits at this time, access to ground-level caves certainly increased after $700 \mathrm{BC}$, yet the cave interiors were kept clean of discarded refuse. This suggests that the caves were regarded as different kinds of places, where special rules applied. For instance, the presence of water pools and their status as water sources probably discouraged pollution. Other notions of ritual cave space may have been formalised as people began living in settlements at the cliff bases, leading to prohibitions against entering the caves.

\section{Between AD 1 and 500}

During the first centuries AD, people expanded their cliff-base settlements, and the cultural use of some of the caves began to show noticeable changes. The first deposit in a cave interior occurred at Upper Cave, involving the discard of scattered ash and charcoal with a few pieces of Codakia sp. and Tellina sp. clamshells, but no pottery or other artefacts. The preference for these particular taxa occurred not only here, but also at other caves since this period, in contrast with the minor role overall of these shellfish at residential sites. It suggests a distinctive, restricted diet, or some other reason for using these taxa at cave sites but not 
elsewhere. Meanwhile, at the naturally lit overhang of Pictograph Cave, people dug a set of pits and used them repeatedly for burning rubbish. This is reflected in thin superimposed layers, probably related to waste disposal, while the cave interior was kept clean. In those pits, the most abundant refuse was Codakia sp. and Tellina sp. shells, further emphasising their role in cave-specific activities.

\section{Between $\mathrm{AD} 500$ and 1000}

Between AD 500 and 1000, a major change in the adjacent coastal plain had an indirect effect on the role of the caves. Sea level fell farther and approached its present-day position, and people began to live on the enlarged sandy coastal plain and take advantage of a new, nearshore, coral-reef ecosystem. As communities shifted to live farther from the caves, the former cliff-base settlements came to be used for only sporadic short-term activities rather than sustained residential occupation. Cave interiors remained clean of midden deposits, except at Upper Cave, while the cultural deposits outside the caves mostly contained Codakia sp. and Tellina sp. shells, with few other species present. Pottery and other artefacts outside the cave mouths appeared much the same as those of the open settlements, but in notably smaller concentrations.

\section{Between AD 1000 and 1700}

The period AD 1000-1700 has yielded the most abundant archaeological information at Ritidian, as it has throughout the Mariana Islands. The abundance of surface-accessible village ruins, profuse amounts of broken pottery with distinctive thickened-rim profiles, and other durable materials make this period appear over-represented (for a thorough review, see Carson 2012b). Houses were made of quarried stone pillars with elevated capitals supporting a wooden superstructure. They were locally known as latte and organised in structured villages as at Ritidian. Stone grinding basins, or lusong, were worked in semiportable small boulders at the residential latte sites, but also in the limestone bedrock shelves outside several caves.

After AD 1000, Ritidian showed its most widespread settlement in latte village ruins, not only throughout the western sandy coastal plain, but also for the first time extending into the rough limestone terrain of the eastern headland. Many of the caves at Ritidian began to accumulate deposits of ash, charcoal and shells, primarily Codakia sp. and Tellina sp. bivalves, contrasting with the latte residential middens primarily of Strombus sp. gastropods. Curiously, the deeper cave interiors still showed no pottery or other artefacts. The density of ash and charcoal varied considerably from one cave to another, being absent from Pictograph Cave, while comprising virtually the entire sedimentary matrix at Hilitai Cave. Additionally, shallow graves began appearing in many cave interiors, as well as at the bases of steep overhanging cliffs immediately adjacent to the caves.

Mortuary practice after AD 1000 most frequently involved interment at the latte houses. The cave burials must therefore have represented a separate tradition, perhaps for 
people who did not belong at designated houses. House burials of this period signified a permanence of place for those who lived there, part of a new formalisation of social relations into stonework features, structured village layouts and access to fixed territories not evidenced in prior periods. If the latte houses were used by family lineages, then alternatives may have been sought for the burial of individuals who had not been initiated by rites of passage, marriage, or other ways of gaining formal household or lineage membership. These exceptions might apply to children, people who died in unusual circumstances or individuals who followed atypical lifestyles.

The research at Ritidian deliberately avoided the excavation of burials, although skeletal elements initially identified in situ were documented and preserved. Limited observations indicate extended-position burials at the latte houses, and a mixture of extended, flexed and secondarily re-deposited burials in pits at caves and cliff-base locales. These patterns were documented previously in Hans Hornbostel's (1925) excavations at a latte complex, and inside Ritidian View Cave, now confirmed by other instances at Lower, Upper and Unnamed Caves.

Ritidian View Cave is the most difficult to access, situated more than $12 \mathrm{~m}$ up a vertical, limestone terrace cliff face. Hornbostel (1925) recounted that the cave had "contained skulls which were removed years ago by the Spaniards", referring to the efforts of Jesuit missionaries to abolish native Chamorro religious practice in the late 1600s. According to local beliefs today, human skulls had been revered in ancestor worship and used when consulting spirits. Inside the cave, Hornbostel documented a top layer of bat guano, covering another layer of rock-fall over a basal layer containing human skulls and other bones, along with the only finds (probably grave offerings) from a deep cave interior: pottery fragments, an adze, and chipped stone and shell tools. The location of the former trench was verified in 2015 , and the loose bat guano was measured to be at least $0.35 \mathrm{~m}$ thick throughout the cave. Additionally, a white-pigment human figure was observed on the rearfacing side of a large cave pillar.

Wherever the white-pigment human figure pictographs were observed, they were 50 $70 \mathrm{~mm}$ tall and consistently drawn at head-level or within an arm's reach above head-level. Many were headless, a feature possibly related to traditions of using skulls in ritual activities (Cabrera \& Tudela 2006), but they could also represent ghosts or spirits, drained of colour and floating. Each white-pigment figure in Ritidian View, Lower, Upper and Pictograph Caves was located in a partial twilight zone, removed from direct sunlight and visible only at certain times without artificial lighting, accentuating the brightness of the white pigment when illuminated.

Outside several caves, lusong grinding basins were created in limestone bedrock shelves attached to the cave formations (Figure 10). They were probably used in the preparation of pigments, medicines or foods prior to entering the caves. Unlike the semi-portable lusong boulders at residential sites, the immovable bedrock versions at caves covered large areas with multiple mortar depressions. Only one case, at Hilitai Cave, included a single depression, whereas all others displayed several depressions of different sizes. This suggests separation in the grinding of different ingredients, or that it occurred at different occasions. 


\section{AD 1700-present}

By 1700, Ritidian and other latte villages had been abandoned as residences, and people were removed from the area. This happened when the native Chamorro people were
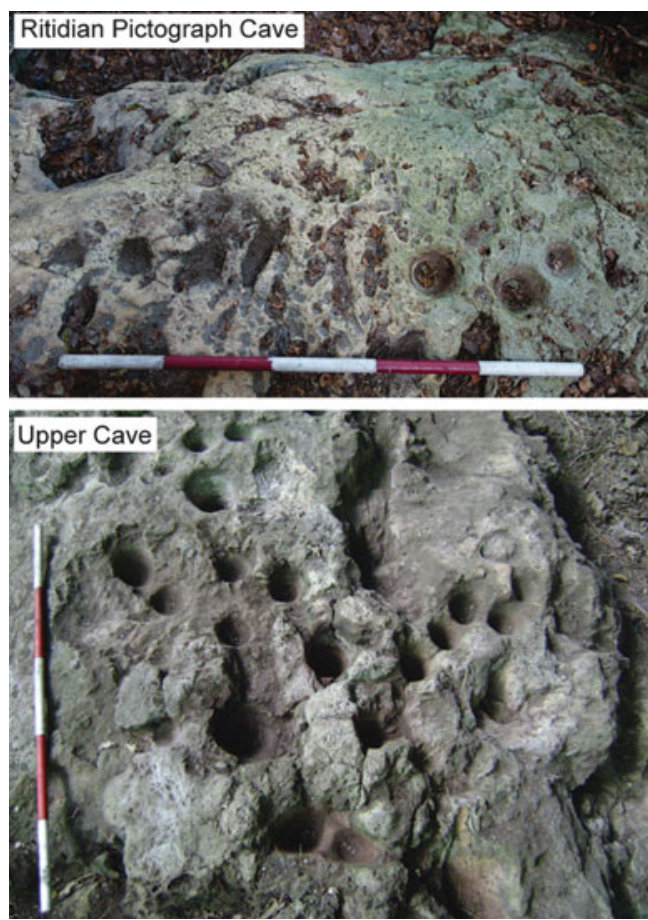

Figure 10. Examples of lusong grinding mortars outside Pictograph and Upper Caves. Scale bars are in $200 \mathrm{~mm}$ increments (photographs by the author). relocated to a few villages controlled by Spanish authorities in the aftermath of Jesuit missionary conflicts and the SpanishChamorro wars (Jalandoni 2014). One of the first Jesuit missionary outposts of the late 1600s was at Ritidian, where Hornbostel (1925) described a "block house" built from the stone elements of latte houses, echoing his report of the removal of skulls from Ritidian View Cave. The interruption of cultural practice for more than 300 years has not diminished the cultural significance of the site today, as the remnants of latte in the jungle, and of rock art in the caves, are regarded as sacred places inhabited by ancestral spirits.

\section{Discussion and conclusions}

Coordinating the archaeological evidence inside and outside the caves allows them to be contextualised as venues for specialised activities that formed an essential function for communities living in contemporary settlements. The central

themes are reminiscent of those from caves in other regions, with suggestions of rites of passage, communication with ancestors or spirits, and commemoration of historical or mythical events. The available material evidence includes different categories of rock art, rare forms of pottery used for purposes clearly different from daily routines, the manufacture of points made from human bone (believed to have had magical properties), and unusual foods that were uncommon in ordinary residential life. Additional information reveals that certain activities occurred outside but in connection to the caves, involving preparation at bedrock mortars and waste-disposal in pits.

Among their various properties, the Ritidian caves are associated with water collection, both from pools in the cave floors, and from ceiling-drip through the limestone. Water supply was vital in the karstic terrain of northern Guam, which lacked rivers or lakes, and where people instead relied on rainwater, coastal seepage flows and, of course, the limestone caves as stressed here. Indeed, surface water is rare throughout the Mariana Islands as a whole, although northern Guam's limestone plateau contains a massive aquifer. Water sources in caves would have been more easily accessible during the oldest settlement period (C) Antiquity Publications Ltd, 2017 
(1500-1100 BC), before the fall in sea level that lowered the water table $1.8 \mathrm{~m}$ over the next several centuries.

Whether due to water supply or other factors, cave interiors were largely kept clean until after AD 1000. Even in later phases, deposits in cave interiors consisted of ash, charcoal and shell, but no pottery or formal artefacts, suggesting restricted kinds of activities. In all time periods, rubbish was mostly discarded outside the caves, occasionally in burning pits, although these patterns appear to have been relaxed in later periods.

With the relaxation of cleanliness restrictions after AD 1000, caves became places of burial, and new sets of social and religious rules were formalised. While a tradition of house burial at the latte villages was perhaps considered ideal in most cases, caves were available for the burial of individuals who, for whatever reason, did not belong to a specific house. The formalisation of stone-built houses after AD 1000 coincided with the use of lusong grinding mortars made in durable stone, including those created at cave entrances. Overall, the archaeological signature of AD 1000-1700 is defined by structured formality in residential life as well as at the caves.

Food remains at the caves were restricted in their variety (primarily Codakia sp. and Tellina sp. shells), but also in quantity, hinting at repeated short-lived episodes involving foods not normally consumed at contemporary residential sites. The limited range of shellfish taxa differs from the feasting events or luxury foods seen at cave sites in other regions (O’Day et al. 2003; Appleby \& Miracle 2012; Hayden 2014), but these patterns could suggest meals eaten during rituals lasting some days and involving only a few people.

The rock art panels can be separated into four different formats of motifs and pigments (see Table 2): 1) white-pigment human figures; 2) black-pigment contorted human figures and geometric shapes; 3) bright red handprints, hand X-rays, extended hand-and-arm prints, and circles; and 4) dull reddish-brown images of compound geometric shapes. For reasons of preservation, these images are not suitable for direct dating assays, but the associated cultural deposits indicate potential oldest ages of $1500 \mathrm{BC}$ at Beach and Pictograph Caves, and 1100 BC at Gate Cave, while all others probably post-date AD 1000. The youngest images are the white-pigment human figures, all at head-level or within arm's reach on the cave walls, superimposed over older bright red handprints in the Pictograph Cave. They are the only images in Lower, Upper and View Caves, where the predominant cultural deposits post-date AD 1000. This possible portrayal of mortuary rituals, ghosts or ancestors further suggests a date post-AD 1000 consistent with the human remains reported in the cave interiors. It should be noted, however, that the carved artefacts of human bone at Beach and Gate Caves are not associated with any white-pigment human figures, but rather with contorted black-pigment human figures at Beach Cave and a paired red handprint and hand X-ray at Gate Cave. The bright red handprints are definitely older than the superimposed white-pigment figures in Pictograph Cave, and a similar age may be proposed for the other red-pigment images in both Pictograph and Gate Caves. The black-pigment images are restricted to dark and high-reaching portions of Beach and Pictograph Caves, where they may represent the oldest cultural presence. The dull reddish-brown geometric patterns of compound elements in Pictograph Cave remain enigmatic in terms of their meaning and dating, and so far they are unknown at any other site in the region. 
The unique and mysterious qualities of the Ritidian caves are best understood when integrated with greater knowledge of the communities who used them. If caves are studied in isolation, then their material records remain either hopelessly puzzling or else susceptible to erroneous interpretation as evidence of routine daily practices. The Ritidian caves are indisputably extraordinary places, where people used unusual artefacts, consumed rare meals, created distinctive artworks and generally behaved in ways atypical of their ordinary lives at other sites. In other words, caves should not be interpreted in isolation from their larger social context, just as societies as a whole should not be characterised without acknowledging the ritual significance of caves.

\section{Acknowledgements}

Paul Taçon and Graeme Barker provided constructive advice to improve this manuscript. I am grateful to US Fish and Wildlife Service (USFWS) employees Brian Leon Guerrero, Emily Sablan, Kyle Ngiratregd, Jaried Calaor, Gabe Cruz, Ryan Deregnier, Joe Schwagerl and Laura Beauregard for their continued support, as well as to my colleagues Rosanna Barcinas, Leonard Iriarte, Rita Nauta and everyone who has encouraged the positive public outreach.

\section{References}

Appleby, J.E.P. \& P.T. Miracle. 2012. Sacred spaces, sacred species: zooarchaeological perspectives on ritual uses of caves, in H. Moyes (ed.) Sacred darkness: a global perspective on the ritual use of caves: 275-84. Boulder: University Press of Colorado.

Bergsvik, K.A. \& R. Skeates (ed.). 2012. Caves in context: the cultural significance of caves and rockshelters in Europe. Oxford: Oxbow.

Brady, J.E. \& K.M. Prufer (ed.). 2005. In the maw of the Earth Mother: Mesoamerican ritual cave use. Austin: University of Texas Press.

Cabrera, G. \& H. Tudela. 2006. Conversations with i man-aniti: interpretation of discoveries of the rock art in the Northern Mariana Islands. Micronesian Journal of the Humanities and Social Sciences 5: $42-52$.

Carson, M.T. 2010. Radiocarbon chronology with marine reservoir correction for the Ritidian archaeological site, northern Guam. Radiocarbon 52: $1627-38$. http://dx.doi.org/10.1017/S0033822200056356

- 2011. Palaeohabitat of first settlement sites 1500-1000 B.C. in Guam, Mariana Islands. Journal of Archaeological Science 38: 2207-21. http://dx.doi.org/10.1016/j.jas.2011.03.021

- 2012a. Evolution of an Austronesian landscape: the Ritidian site in Guam. Journal of Austronesian Studies 3: 55-86.

- 2012b. An overview of latte-period archaeology. Micronesica 42: 1-79.

- 2014a. Paleo-terrain research: finding the first settlement sites of Remote Oceania. Geoarchaeology 29: 268-75. http://dx.doi.org/10.1002/gea.21457
- 2014b. Contexts of natural-cultural history: a 3500-year record at Ritidian in Guam, in M.T. Carson (ed.) Guam's hidden gem: archaeological and historical studies at Ritidian (British Archaeological Reports international series 2663): 1-43. Oxford: Archaeopress.

- 2014c. First settlement of Remote Oceania: earliest sites in the Mariana Islands. New York: Springer.

Carson, M.T. \& H. Kurashina. 2012. Re-envisioning long-distance Remote Oceanic migration: early dates in the Mariana Islands. World Archaeology 44: 409-35.

http://dx.doi.org/10.1080/00438243.2012.727342

Clottes, J. (ed.). 2003. Chauvet Cave: the art of earliest times. Salt Lake City: University of Utah Press.

Dickinson, W.R. 2000. Hydro-isostatic and tectonic influences on emergent Holocene paleoshorelines in the Mariana Islands, western Pacific Ocean. Journal of Coastal Research 16: 735-46.

Dixon, B. \& R. Schaefer. 2014. Archaeological investigation of caves and rock shelters on Guam and Tinian: a synthesis of their use through time. Journal of Pacific Archaeology 5: 52-74.

HaYden, B. 2014. The power of feasts: from prehistory to the present. Cambridge: Cambridge University Press. http://dx.doi.org/10.1017/CBO9781107337688

Hornbostel, H. 1925. Unpublished field notes of 1921-1924. Manuscript on file. Honolulu (HI): Bernice P. Bishop Museum.

(C) Antiquity Publications Ltd, 2017 


\section{Cultural spaces inside and outside caves}

JaLANDONI, A. 2014. Conflict at contact: late $17^{\text {th }}$-century Spanish missions and la reducción in northern Guam, in M.T. Carson (ed.) Guam's hidden gem: archaeological and historical studies at Ritidian (British Archaeological Reports international series 2663): 53-63. Oxford: Archaeopress.

McNeill, J.R. 2005. Putting the dead to work: an examination of the use of human bone in prehistoric Guam, in G.F.M. Rakita, J.E. Buikstra, L.A. Beck \& S.R. Williams (ed.) Interacting with the dead: perspectives on mortuary archaeology for the new millennium: 305-15. Gainesville: University Press of Florida.

Montello, D.R. \& H. Moyes. 2012. Why dark zones are sacred: turning to behavioral and cognitive science for answers, in H. Moyes (ed.) Sacred darkness: a global perspective on the ritual use of caves: 385-96. Boulder: University Press of Colorado.

Moyes, H. (ed.). 2012. Sacred darkness: a global perspective on the ritual use of caves. Boulder: University Press of Colorado.
Nunn, P.D. \& M.T. Carson. 2015. Sea-level fall implicated in profound societal change about 2570 cal yr BP (620 BC) in western Pacific Island groups. Geo: Geography and Environment 2: 17-32. http://dx.doi.org/10.1002/geo2.3

O’Day, S., W. van NeEr \& A. Ervynck (ed.). 2003. Behavior behind bones: the zooarcheology of ritual, religion, status and identity. Oxford: Oxbow.

Pastoors, A. \& G.C. Weniger. 2011. Cave art in context: methods for the analysis of the spatial organization of cave sites. Journal of Archaeological Research 4: 377-400. http://dx.doi.org/10.1007/s10814-011-9050-5

Tabarosi, D. 2006. Karst inventory of Guam, Mariana Islands (Technical Report 112). Mangilao: Water and Environmental Research Institute of the Western Pacific, University of Guam.

TAÇON, P.S.C. 2005. The world of ancient ancestors: Australian Aboriginal caves and other realms within rock. Expedition 47: 37-42.

Received: 27 October 2015; Accepted: 1 February 2016; Revised: 5 February 2016 